Article

\title{
Natural Capital, Domestic Product and Proximate Causes of Economic Growth: Uruguay in the Long Run, 1870-2014
}

\author{
Silvana Sandonato ${ }^{1}$ and Henry Willebald ${ }^{2, *}$ \\ 1 PHES, Programa de Posgrado, Facultad de Ciencias Sociales, Universidad de la República, \\ 11200 Montevideo, Uruguay; chivilive@gmail.com \\ 2 Facultad de Ciencias Económicas y de Administración, Universidad de la República, \\ 11200 Montevideo, Uruguay \\ * Correspondence: hwillebald@iecon.ccee.edu.uy; Tel.: +598-24-131-007
}

Received: 30 November 2017; Accepted: 27 February 2018; Published: 6 March 2018

\begin{abstract}
The debate on the relationship between natural resources abundance and economic growth is still open. Our contribution to this field combines a long-run perspective (1870-2014) with the study of a peripheral country in the world economy (Uruguay). The purpose is to build a historical series of natural capital and contrast its level and evolution with the level and growth of GDP, as well as the proximate causes of its economic growth (produced and human capital, exports and terms of trade). We show that natural capital has tended to decline in importance in the economy, while simultaneously becoming more diversified. Although this evolution is consistent in historical terms, we do not find a causal relationship between the abundance of natural resources and economic performance. Instead of a direct relationship, the proximate causes appear to have been important in explaining the evolution of natural capital when we consider three stages of economic growth: physical capital and terms of trade during the agro-exporter model; human capital and exports during the period of import substitution industrialization; and terms of trade from the 1970s afterwards. These factors cause natural capital but not the other way around, leading us to conclude that an abundance of natural capital is an endogenous process.
\end{abstract}

Keywords: natural capital; economic growth; Uruguay

\section{Introduction}

We identify the concept of "natural resources" with those assets which originate from nature-land, forests, minerals - and can be exploited for economic purposes. In principle, such assets should provide at least three advantages for undeveloped economies [1]. First, the income flow from resource exploitation can finance higher levels of public and private consumption, improving the living standards of deprived segments of the society. Second, the extraction of natural resources can support investment in physical and human capital, either directly by use of resource rents, or indirectly because the natural resources can serve as a guarantee to borrow abroad. Third, since government can place taxes on rents or directly on the exploitation of the resources, this can provide the revenues needed to finance fundamental public goods, including infrastructure, health and education.

However, in recent decades, it has been noticed that large national resource wealth does not assure success and, on the contrary, it may even seriously impinge on economic development. Many Latin American, African and Asian countries possess large energy, mineral and forestry wealth and yet their inhabitants continue to experience low quality of life [2]. The literature named this puzzling phenomenon the "natural resource curse" [3], which refers to the paradox that economies endowed with abundant natural resources tend to experience deficient economic growth and worse development 
outcomes than economies with scarce natural resources. The resource curse thesis has focused, mainly, on non-renewable assets because such resources have the worst consequences on economic growth $[4,5]$.

In Section 2, we present a review of different approaches (in conceptual and empirical terms) that refer to the "curse" and "blessing" of natural resources. The history of economic thought on the matter has moved from an extended consensus about natural wealth constituting an engine of the economic growth - a dominant idea from the end of the 19th century to the 1950s-to an extended confidence about the low probability of creating conditions where resource-based development can be sustainable. Nevertheless, recently, other authors have criticized this viewpoint and have questioned the intensity and the causality of the relationship.

Can economic history offer new approaches about this discussion? Can the study of long-run economic processes contribute with new insights for interpreting this apparent paradox? We answer both questions affirmatively. The analysis of resource-rich countries is an interdisciplinary field and "draws on macroeconomics, public finance, public policy, international economics, resource economics, economic history and applied econometrics. It also benefits from collaboration with political scientists and historians" [6] (p. 407). As well as, one of the "most interesting aspect[s] of resource-abundant countries is not their average performance but their huge variation" [7] (p. 242). In other words, to study particular cases constitutes a valuable effort to understand the dimensions and the mechanisms behind the curse and the blessing of natural resources.

Our research is part of efforts to include long-run considerations in the debate and to identify historical specificities that confirm that the relationship is not an immutable process but could respond to a broad range of conditions, variables and circumstances. In Section 3, we explain that Uruguay is an excellent case study for evaluating this matter for three reasons: (i) Uruguay is a country historically described as a natural resources-abundant economy, but this characterization only holds for some dimensions of the economic process; (ii) Uruguay is a case of abundance of non-mineral natural resources which allows us to investigate an area where the literature always has paid little attention; (iii) we develop a novel series of natural capital that represents a better approximation to the concept of "abundance" in distinction from "dependence", which has been at the core of recent literature. This topic is one of the main contributions of our article in two ways. On the one hand, we propose a long-run estimation of natural capital, annually, from 1870 to 2014, considering five components: pasturelands, croplands, timber and non-timber forestry and protected areas. On the other hand, we apply the World Bank's methodology to account for the natural capital but we propose correcting and improving upon the original assumptions to capture the historical specificity over such a long period. Therefore, we devote Section 4 to the description of our empirical strategy and methodology, including the principal assumptions and details related to each component.

We present the results in Section 5. To start with, we consider the main stylized facts based on our estimates of the natural capital series (1870-2014) to evaluate the historical consistency of our results. The growth in natural capital does not cause economic growth nor does the expansion of GDP cause natural capital growth. Instead of this direct relationship, other channels likely served as physical capital and terms of trade during the agro-exporter model, human capital and exports in the industrialization period and terms of trade again from the 1970s afterwards in the so-called re-globalization period. These factors cause natural capital but the causality in the other direction is not confirmed, leading us to conclude that abundance of natural capital is an endogenous process. We discuss the main results in Section 6 and we conclude in Section 7.

\section{Theory and Empirical Approaches}

We review, briefly, the literature about the relations between abundance of natural resources and economic trajectories of countries and regions. First, we survey theoretical frameworks considering fives approaches: natural resource abundance as a blessing; production structure approach; crowding-out approach; institutional change and factor endowment; and the economic history approach [8]. 
Second, we refer to empirical tests on the effect of natural resources on real evolution of the economy, the effects on variables related to economic expansion and a critical view of the curse.

\subsection{Theoretical Frameworks}

\subsubsection{The Blessing of Natural Resource Abundance}

Initially, from a theoretical point of view the relationship between abundance of natural resources and economic performance offered an extended consensus about natural wealth constituting an engine of economic growth. This was the dominant idea until, at least, the mid-20th century.

In the last decades of the 19th century and up to WWI, several peripheral economies experienced a real economic boom related to the industrial development in Western Europe and the US. The "core" of the world economy required low-priced natural resources from the new settlements and the colonized regions needed to obtain financial resources and labor to increase their ability to provide exports based on the exploitation of natural resources. Conceptual frameworks such as the "staples theory" and the "vent for surplus theory" consider the presence of excess resources that are insufficiently exploited in economies usually small and closed and trade allows to foster exports and growth because natural resources are used productively [9].

In addition, there is a wide range of literature about the US that underlines the favorable influence that natural endowments had on welfare levels in the late 19th and early 20th centuries. Mining promoted the establishment of prestigious educational centers and diffused knowledge to other activities $[10,11]$ in a sense close to the notion of biased technological transformation encouraged by the availability of natural resources [11]. Recently, the studies have also deeply analyzed other successful cases as Australia, Norway, Sweden, Chile, Botswana and Indonesia, where the abundance and adequate management of natural resources has been able to promote economic growth.

\subsubsection{Production Structure Approach: The Difficulties of a Primary Sector Specialization}

We identify a couple of views. First, a perspective that considers the allocation of resources among economic activities with different spillovers and underlines the effects of specialization in economic growth. Economies whose economic performances are founded on natural resources and where secondary and tertiary sectors represent a modest participation in the production structure will expand moderately and evidencing serious limitations to promote the structural change. Within the mainstream of economic growth research, this field is represented by the Developmentalism of the 1950s and the endogenous growth models of the 1980s [12]. Two alternative visions to this mainstream literature offer other arguments to interpret the relationship between specialization in primary products (generated from the exploitation of mineral, forest and land wealth) and low economic growth rates. One of them is related to the Marxist, Dependency and Structuralist traditions, which consider the unequal development view [13-15]. The other corresponds to the recent post-Keynesian and post-Kaldorian theories, which discuss income elasticities and external constraints on growth [16], as well as the formal characterization of technological dynamics in the Neo-Schumpeterian and Evolutionary Schools [17].

Second, according to the so-called Dutch disease hypothesis [18-20], economies with abundant natural resources are subject to successive fluctuations in their levels of economic activity because commodity prices are volatile and periodically new exploitable natural resources are discovered. As a result, the economy will become specialized in the exploitation of natural resources and, in consequence, economic growth will be affected. Recent research, which refers to the endogeneity of resource dependence, argues that volatility may be the quintessence of the resource curse6.

\subsubsection{Crowding-Out Approach: Natural Resources Displace Other Types of Capital}

In the formulation of the most extended models, abundance or heavy dependence of natural resources has effects on some variable " $\mathrm{x}$ " which hinders economic expansion. Theorists and empirical 
researchers have identified the channels that relate both processes [21]. These mechanisms are interpreted in terms of a crowding out effect where the abundance of natural capital displaces other types of capital and hamper economic growth.

Large natural resource rents, combined with property rights poorly defined, imperfect markets and weak legal structures, may lead producers to adopt uncontrollable rent-seeking actions. These actions deflect resources away from activities that are socially more productive, causing a false sense of security and inducing the government to disregard the promotion of high institutional quality [22-25]. Natural capital may have different effects on economic performance depending on the conditions of the endowments [26]. "Point resources" (e.g., mineral and energy resources, activities with intensive use of capital) and "diffuse resources" (e.g., cropland and livestock) contribute to different development potential. "Point resources" cause greater opportunities for rent-seeking and corruption than "diffuse resources" and the adverse consequences are more negative [27,28], especially with the low quality of the institutions and the different levels of resource appropriability [29]. Abundance of natural resources may affect accumulation of human capital because predominates a high level of non-wage incomes and, usually, these economies tend to underestimate the value of educating and training the society in the long run [30-32]. Finally, abundant natural resources provide an ongoing future flow of rents and social welfare seems less bound to intertemporal transferences of produced capital to the future [21], thereby inducing low saving rates [7].

\subsubsection{Institutional Change and Factor Endowment Approach}

This approach argues that the main explanation of economic development results from the interaction of basic exogenous factors (ultimate causes as climate, topography, disease and environmental factors) and institutional legacy [33].

Colonization strategy was influenced by those natural conditions. Places with worse conditions for settlement and with high mortality rates among colonists (malaria, yellow fever), were characterized by the formation of extractive states. But, on the other hand, if colonizers could safely settle in a region they formed and promoted high quality institutions. The colonial legacy of the institutional matrix persists in the long run and it results in a fundamental factor in determining economic development [34]. However, the determinant factor endowment was not just the abundance of land and natural resources in relation to labor but also the type of land, the climatic conditions and native populations in terms of size and density $[35,36]$. The extreme differences in terms of wealth and human capital inequality, as well as political influence, across the New World societies have a fundamental importance in the explanation. The causal relationship is between natural endowments, conditions of social and economic inequality and the creation of an institutional matrix capable to generate the requirements for sustaining the economic development in the long run.

\subsubsection{Economic History Approaches}

Recent efforts from economic history have offered new evidence, approaches and emphasis that respond to Van Der Ploeg's claim referring to the relevance of promoting collaboration between political scientists, historians and economists to understand, from an economic point of view, the relationships between natural resources and economic development. Willebald, Badia-Miró and Pinilla (2015) [8] highlight three answers to the question: what do we learn from history? (i) abundance of natural resources is non-neutral for economic development; (ii) abundance is an endogenous process; (ii) institutional quality is the key factor for development of abundant natural resources to have good economic outcomes.

First, there is evidence of a close relationship between abundance of natural resources and development. Only $5 \%$ of the total world wealth was comprised of natural capital in the beginning of the 21st century. However, divergence between levels of development was the dominant feature: this ratio for high and low-income countries was, respectively, $2 \%$ and $30 \%$. 
Second, abundance of natural resources does not refer to a static concept. "Abundance" is a process that receives the influence of modifications in the relative prices and the structure of factor endowments and to progress it requires investment, labor, technological change and proper institutional arrangements. Therefore, this "abundance" is part of the evolution of the economic system and, in these terms, we identify the endogeneity of natural capital as a typical historical feature. In other words, "natural resource abundance was an endogenous, 'socially constructed' condition that was not geologically pre-ordained" [10] (p. 203).

Finally, the relevance of the institutional quality is expressed in the ability of institutions to restrict opportunities of rent-seeking, to regulate the political competition and participation and to deal with transactional risk through suitable enforcement of property rights of natural resources.

\subsection{The Empirical Evidence of the Resource Curse}

This evidence referred to the curse of the natural resources is quite diverse and can be characterized in three different groups [2]. The first of them regards Sachs and Warner's cross-sectional study and deal with different indicators to approximate resource abundance/dependence. The second set of exercises concentrates on economic elements relevant for growth that can be influenced by natural capital. The last group sheds doubt about the validity of the econometric exercises and the accuracy of the empirical tests.

\subsubsection{The Impact of Natural Resources on Economic Growth}

Empiric on the curse hypothesis begun with a couple of case studies $([3,37])$. However, the crosssectional analysis of [38] is considered the seminal empirical contribution for a long series of studies "in the pursuit" of the curse.

Sachs and Warner $(1995,2001)$ considered a large number of economies for the period 1970-1989 and verified that natural resource dependence and economic growth are negatively correlated. These articles inspired subsequent research that has examined the direct and indirect relationships between dependence of natural resources and economic growth. Multi-country comparisons predominate and the majority of the studies [2] consider a dependence indicator to proxy the influence of natural resources on economic growth, for example: primary exports over GDP [38-42]; rents from natural resources over GDP [43-48]; natural capital on national wealth [21,49]; and mineral exports over total exports [50-52]. However, other studies have considered a more adequate proxy to abundance of natural resources as the total natural capital, mineral resource assets in dollars per capita $[53,54]$ and subsoil wealth $[41,53,55]$ (see [2] for a review of the literature).

In addition, resource curse hypothesis also has been discussed in many single country studies, with $[3,37]$ being the two main antecedents. Several of these studies explain the failure of many African economies [25,56], identify cases where the curse was avoided ([57] for the US, [58,59] for Botswana, for Chile [60], for Norway [61], for Peru [62] and for China [63]) or cases where the evidence confirms some type of curse (for Angola [64] and Venezuela, for Ghana [56], for Mexico [65] and Venezuela, for Nigeria [66]).

\subsubsection{The Impact of Resources on Factors Linked to Growth}

Numerous works additionally obtain evidence of relationships between natural resource dependence and factors which are tightly linked to economic success. These exercises include human capital [49,52,67-69], savings rates [21,50,56,70], exports of manufactured products [71], physical investment, schooling and openness [57], fiscal policy [72] and institutional quality [42,73]. This empirical evidence responds to the crowding-out approach presented previously. According to this conceptualization, the negativistic effect of natural resource richness on economic growth is seen as coming from their adverse effect on drivers of economic growth. 


\subsubsection{Is This Apparent Paradox a Red Herring?}

Since previous literature came to understand the specific mechanisms through which the curse operated, a new trend has emerged. This new approach is to question the whole curse hypothesis as a "red herring" [54] or a "statistical mirage" [2].

According to [54], a fairly extended way of measuring - the percentage of exports with respect to GDP- is endogenous, which seriously challenges one of the more fruitful stream of the literature (included the pioneer Sachs and Warner's work). The ratio is dependent on a country's economic policies and the institutional frame that have effects on both GDP level and growth, which affects both sides of the equation. An attempt is made to surpass this issue using instrumental variables.

An alternative approach considers the time samples used as the main claim of the critic. In this sense, [74] assert that the arguments proposed by the abundance of natural resource curse studies are in many instances due to a deficient interpretation of information. The major part of the studies that finds a curse uses a time horizon that begins between 1965 and 1970. This period is not convenient since commercial exploitation in the oil-exporting countries began before 1950, without considering an important period of analysis. The sample period in question also is considered in [53,75-79].

The time sensitiveness of natural resource curse points to other causal factors involved. Manzano and Rigobon (2001) assert that it is plausible that the resource curse model of [38] reflects the effects of the international oil price shocks of the 1970s, instead of an inherent trend for resource-abundant countries to experience low economic growth.

The better part of these critical academic works demonstrates that if natural resource richness is used instead of indicators of natural resource dependence, the effect of natural resources is positive. Also, taking into account the possibility of non-linear or non- monotonic relationships between the exploitation of natural resources and economic growth, the changing character of the relation in the long run also appears as an issue [2].

\section{Hypothesis and Empirical Strategy}

\subsection{Historical Overview and Reasons to Study Uruguay}

Uruguay is a typical new settlement economy in the sense defined by [80] and constitutes, together with Argentina, Australia, Canada, Chile, New Zealand, South Africa and the US, the "temperate economies" that [81] (p. 195) identifies as "the group of non-European countries which in [the beginning of] twentieth century can be classified as developed."

Uruguay prospered thanks to its flourishing agrarian activities. Historically, it was characterized as a country with plenty of natural resources and small population, mostly descendants of European immigrants [82]. Economic growth was initially supported by exports of agrarian products that met an expanding international demand. In the final decades of the 19th century Uruguay had achieved levels of income per capita that exceeded those corresponding to the several leading European economies [83].

These economies had the challenge of going from being a settler society, highly specialized in primary commodities, to some form of post-settler configuration [84], with a more diversified production structure.

In the case of Uruguay, literature identifies three historical phases of development $[85,86]$. During the first globalization, growth combined the progressive consolidation of the domestic market [87] with an export expansion based on a few primary commodities (over 1870-1879, wool, hides and preserved meat represented $60 \%$ of total exports; in the decade prior to WWI, the same products represented almost 70\%) [88]. In this period, the Uruguayan economy achieved high income levels; over 1870-1879, the GDP per capita of Uruguay was 90\% of the level of GDP per capita of "core" countries-average of France, Germany and UK — and, in the decade preceding WWI, the same ratio was almost $80 \%$ [89]. The primary activities (agriculture and mining) represented about one-third of economic structure in 1870-1930 while the proportion of manufacturing averaged $12 \%$ of GDP [90]. 
After some years of economic turmoil in the early 1930s, Uruguay adopted inward-looking oriented policies focused on a strategy of industrialization by substitution of imports (ISI) to encourage growth and economic development [91,92]. The industrial sector increased in terms of GDP, reaching almost one-third of total output, in opposition to the falling share of primary activities. In the decade following the WWII, the country experienced rapid growth based on the manufacturing industry in a process that extended until the end of the 1950s [93], when a long period of stagnation and high inflation started [94]. This situation was not overcome until 1970, when new measures of economic policy were implemented based on a gradual openness of economy, increasing financial liberalization and regional trade agreements [86]. The strategy of promoting export of non-traditional goods get satisfactory economic results, with the expansion of several industrial branches (manufactures of textiles, tanning and dressing of leather and footwear leather, electrical machinery and apparatus, transport equipment and paper products) and high economic growth rates for the whole economy. The liberalization process continued in the 1980s and 1990s and the manufacturing sector declined drastically as a share of the economy. During these decades, the economy went through two deep crises, one in the 1980s and another in the 2000s. From 2003-2004 to the present, Uruguay has experienced a long expansion cycle that suggesting a beginning of an income convergence process with developed countries [95], as contrasted with the trajectory evidence since the 1960s.

The expansion cycle is founded on high rates of fixed capital formation, with increased involvement of direct foreign investment in the economy-focused on competitive agro-industrial sectors-and the increase of exports supported by higher volumes and prices [96]. The Uruguayan economy has continued to strongly specialize in commodities and services based on natural resources, which comprise $70 \%$ of total exports [95]. The production structure has not experienced major transformations [96] and the expansion cycle has been driven by agriculture. The major part of agricultural activities has experienced significant changes in terms of productivity, technological progress, logistics and transport activities and public policy directed to the sector. In this sense, historical and "traditional" agricultural sectors have made way to modern activities with important incorporation of technology and $\mathrm{R}+\mathrm{D}$ activities.

Considering this long-run economic evolution and the previous theoretical and empirical antecedents (presented in Section 2), Uruguay is an interesting case to study for three reasons.

\subsubsection{Duality of the Structural Change}

A strong consensus exists regarding the historical characterization of Uruguay as a natural resource-abundant economy $[97,98]$ that founded its economic development on the basis of exploitation of this natural wealth. The influence of natural resources on economic development was diverse and, to some extent, in opposing directions. Whereas industrial manufacturing increased significantly as a share of the economic structure at the expense of the primary activities from the 1930s to the 1960s [99] and afterwards services gained a predominate position in total value added, other areas of the economy did not experience similar transformations. In fact, nowadays, Uruguay is clearly identified as a natural resource-abundant economy when we evaluate its export structure but when we consider the structure of the economy as a whole, this characterization is not so evident. This last assertion is confirmed by World Bank data, where Uruguay does not appear as an economy especially rich in terms of natural resources.

Therefore, according to the historical evolution of Uruguay, we propose our first working hypothesis: we expect a high relevance of natural wealth during the agro-exporter model but a reduced share in the economy after the 1930s, when the structural change led to an increasing role of manufacturing and services in linkages between economic sectors. This hypothesis would be an (indirect) expression, in the long run, of the stylized fact of economic growth identified in [100]; i.e., those economies with the highest GDP per capita tend to have shares of natural capital, in their total wealth, lower than the poor economies. 
In this sense, we expect that the abundance of natural resources caused economic growth during the last third of the 19th century and the first decades of the 20th century; however, this influence faded in the following decades. In other words, we assume that there would have been a positive relationship between natural resources and economic growth in the first stages of development and a progressive reversal of the relationship in the following decades. This is our second working hypothesis.

\subsubsection{The Relevance of Studying the Non-Mineral Wealth}

The literature has focused on subsoil resources and has underestimated the role of non-mineral natural wealth. Different types of natural resources may affect differently economic performance [23]. "Point resources" (e.g., mineral and energy resources) can create greater chances for rent-seeking and corruption than the "diffuse resources" (e.g., cropland and pastureland) representing more serious consequences for economic growth. Economic performance is usually more affected when natural resources—and the rents derived from their exploitation [79]—are more easily captured and controlled by a narrow elite. However, these arguments about economic growth depending on the type of resources does not necessarily mean that one should leave non-mineral wealth out of the analysis. In addition, almost a $40 \%$ of the total worldwide wealth is comprised of subsoil assets. In other words, the excessive academic concentration in natural resources such as oil, gas and minerals has probably impeded advance in knowledge of several dimensions of the process. We contribute new evidence on this matter by considering the Uruguayan economy, where resource wealth is almost entirely non-mineral. Implicitly, with the hypothesis presented in the previous section, we are assuming that the abundance of natural resources is an exogenous variable for Uruguay. Considering that the main components of the natural capital are pastures and croplands and that the exploitation does not require-relative with "point resources"—huge capital outlays or special conditions, the hypothesis seems, at least operatively, plausible.

\subsubsection{Natural Capital as a Better Proxy for the Abundance of Natural Resources}

Following [38], primary exports over GDP have been the preferred indicator in the naturalresource-and-growth literature. However, this measure seems an unsatisfactory indicator of natural resource abundance for two main reasons. On the one hand, the exports-to-GDP ratio as a representation of the abundance of natural resources is questioned and particularly so for cases comparable to Uruguay with similar processes of dual structural change. On the other hand, empirical exercises present problems of endogeneity because they suffer from third factors as fiscal and social policies, taxation and institutions that have effects in both sides of the equation. According to [53,54], the measure of natural capital proposed by $[100,101]$ overcomes these criticisms and offers more acceptable estimations. The indicators of natural resources proposed by the World Bank evaluate different components of natural wealth considering the net present value of expected rents and we will apply this methodology for long-run estimates and the historical analysis (see below the discussion). However, the advantage of this measure is not only from an empirical point of view. World Bank data is the best proxy to test the natural resource curse hypothesis because the proposal to use natural capital as a measure for resource abundance is, conceptually, superior. This measure of natural resource wealth is consistent with a broader concept of an economic wealth indicator-that considers natural, produced, human and institutional assets-and, consequently, with a more rigorous idea of economic growth. In this sense, it is possible to distinguish, in a more convincing conceptual and empirical manner, between resource dependence and resource abundance [102].

\subsection{Empirical Strategy}

We propose a first attempt to count the natural capital for a periphery economy on an annual basis, applying the World Bank's methodology, correcting the initial estimates, adapting the assumptions to the historical analysis and offering a very long run perspective to cover 144 years of history (1870-2014). Our efforts to cover so long a period are based on, at least, two kinds of considerations. One, we expect 
to contribute to the debate about the mechanisms that link natural resources and economic growth and, conceptually, this is a matter inevitably concerning the long run. Even, the consideration of long run periods will allow to identify changes in the relation between these measures of natural resources and economic growth concepts. Two, this will allow to overcome the previously mentioned limitation of many resource curse studies referred to the time samples used in the empirical tests.

Therefore, initially, we present, adapt and revise the World Bank's methodology for applying these concepts for historical estimates. Then, we present the long-run evolution of the natural capital and identify how consistent, in historical terms, this trajectory is according to the national historiography. Finally, we test different causality exercises to find evidence about the direction of the influence between variables.

\section{Materials and Methods}

\subsection{Natural Capital Estimation}

The approach used in our natural capital estimation from 1870 to 2014 is based on the World Bank methodology presented in $[100,101]$ (in the following, we present the first advances of the Master Thesis in Economic History of Silvana Sandonato titled: "Capital Natural y crecimiento económico en Uruguay en el largo plazo (1870-2014)," PHES-FCS-Universidad de la República, Uruguay; which will be defended in 2018). This methodology rests on the well-established economic principle that asset values are measured as the present discounted value of economic profits over the life of the resource. This value, for a particular economy and type of resource, is given by the following expression:

$$
V_{t}=\sum_{i=1}^{t+T-1} \frac{\pi_{i} \cdot q_{i}}{(1+r)^{(i-t)}}
$$

where $\pi_{i} q_{i}$ is the economic rent at time $i,\left(\pi_{i}\right.$ represents unit rent and $q_{i}$ denotes production), $r$ is the social discount rate and $T$ is the lifetime of the resource.

Natural capital, according to the World Bank dataset, is built from estimates of cropland, pastureland, forests, metals and other minerals, coal, oil, natural gas and the inclusion of the "protected areas". Cropland is represented as a flow of land rents over a 25-years horizon (one generation). Specific rental rates for cereals fluctuate between $30 \%$ and $50 \%$ of the gross value of production (wheat, rice, maize) and they are used to calculate the valorization of cereal lands. Then, the rest of lands are valued at $80 \%$ of this rate to allow the possibility that other types of crops are likely to yield inferior returns. Pastureland is valued similarly to cropland but the rental rate is $45 \%$ of the gross value of livestock (considering wool, meat and milk). For timber, there are two options for valuation depending of the sustainability of the exploitation. First, when exploitation is sustainable-i.e., the harvest rate is lower than the annual growth rate of the forest-the resource is measured according to the present value of a constant resource rent in a period of 25 years. Second, in the other case, the present value of a constant resource rent over less than 25 years (depending on the extraction rate) is considered. Non-timber rents are evaluated by assuming that a tenth of the area destined to forest is exploited for production different than timber. Protected areas are measured using an opportunity cost approach, which considers that the value corresponding to pastureland is assigned as a proxy for this type of resource. Minerals, metals and fossil fuels are considered as the present value of a constant flow of resource rents for the life of proven reserves (bauxite, copper, iron ore, lead, nickel, phosphate rock, tin, zinc oil, coal, gas). In cases where there are no data on reserves, a time to exhaustion of 25 years is assumed. This estimation includes information for over 120 countries for the years 1995, 2000 and 2005.

The immediate antecedent of the present article is [103], which applies the methodology presented in [100], although it additionally provides a review of assumptions, components and statistical sources which take into account the specificity of Uruguay within the region and among countries with a similar development process. This estimate—corresponding to 1990, 1995, 2000, 2005 and 2010—uses a social discount rate calculated for domestic social investment projects and includes data series for 
country-specific mineral resources and uses specific growth rates for Uruguay. This analysis offers evidence regarding the dynamics of the proximate determinants of natural capital and allows us, in turn, to recognize the drivers and components of the current path of national growth. In [104], an annual estimation is offered for 1990-2011.

These estimations consider several fixed parameters: social discount, rental and expected growth rates. The fixed parameters applied for the estimations are based on contemporary values, without considering the long-term historical specificity. The historical context of our work leads us to make changes to this methodology, which means an important contribution of this article.

There are four main modifications with respect to the previous methodology. While the Word Bank:

1. considers only expected production, we consider, whenever it is possible, output actually recorded, except from 2015 to 2038, where we had to project productions in order to obtain the present discounted value for 1991 to 2014 . When historical data were not available, we use different estimation techniques to complete the series.

2. considers fixed production rates of return, we consider rents of natural resources actually received, which are therefore variable over time.

3. considers a fixed social discount rate, we consider an annual variable rate which we estimate.

4. assumes a fixed growth rate of future incomes, we take advantage of the information constructed and forecast future rents according to past trajectory (144 years) of the rents.

The first and second changes will be explained for each type of natural resource. Estimations of social discount rates are briefly explained below and described in detail in Appendix A.

The social discount rate or consumption rate of interest (CRI) is defined as the rate at which the marginal welfare of consumption falls over time, which may be decomposed into the formula:

$$
C R I=\delta-L+(\mu g)
$$

$\delta=$ pure time preference

$L=$ changing life chance (negative sign)

$\mu=$ marginal utility of consumption

$g=$ expected consumption growth rate

For the estimation of $C R I$ we follow the methodology presented in $[105,106]$ using own elaboration from data presented in [107]. (See Appendix A).

We assume that the time of exhaustion of resources is 25 years, which roughly coincides with one generation (the same assumption was made by the World Bank). To consider a longer exhaustion time would require predictions of total rents for longer time horizons, which have less weight since they are more heavily discounted. This would mean including predictions further into the future which have marginal contributions in the final estimation. Finally, the level of uncertainty rises as the agents look toward a more remote future.

We use 2005 prices to value income from every resource, annual rent rates for each resource, an annual social discount rate and real values for the total rent up to 2014.

\subsection{Natural Capital by Component}

\subsubsection{Cropland}

Cropland wealth is computed as the present discounted value of rents derived from lands used for cultivation. Annual land return is the sum of returns from: apples, barley, beans, green beans, broad beans, cabbages and other brassicas, canary seed, carrots and turnips, chilies and peppers, cottonseed, garlic, grapefruit (included pomelos), grapes, groundnuts with shell, lemons and limes, linseed, maize, green maize, melons (included cantaloupes), oats, olives, onions, oranges, peaches and nectarines, pears, peas, plums and sloes, potatoes, pumpkins, squash and gourds, quinces, rapeseed, 
rice, seed cotton, sorghum, soybeans, sugar beet, sugar cane, sweet potatoes, tangerines, mandarins, clementine, satsumas, tobacco, tomatoes, fresh vegetables, watermelons and wheat, in all cases we assume that the products are sold at prices obtained in international markets.

We gather information about the physical volume of production of each commodity from 1870 to 2014, valued at 2005 prices. To obtain annual income from crops, we estimate an annual rental rate derived from [107] and additional estimates provided by the authors. In this study, the estimates of land rents do not distinguish between cropland and pastureland and we use the same rental rates for both activities, with this rate change over time according to the ratio of land rents and agricultural value added (in current prices). The rate corresponding to 2005 is $32 \%$ and our calculations from national accounts data-assuming that one-third of the production corresponds to agricultural services-is $30 \%$; then we consider the rates reported in that work to be roughly correct. Finally, we project the cropland rents from 2015 to 2038 using standard forecasting methods to represent the sustainability of present cultivation techniques.

\subsubsection{Pastureland}

Pastureland wealth is computed as the present discounted value of rents derived from lands used for livestock. Annual returns from pastureland is the summation of returns from all pastureland outputs considered: meat, milk, wool, leathers, eggs and honey, valued at international prices.

We gather information about the physical volume of production of each commodity from 1870 to 2014, valued at 2005 prices. In order to obtain annual pastureland incomes, we estimate an annual rental rate derived from [107] and other estimates provided by the authors (see the previous explanation). Finally, we project the pastureland rents from 2015 to 2038 to reflect the sustainability of present grazing practices.

\subsubsection{Mineral Resources}

Mineral wealth is computed as the present discounted value of rents derived from mineral exploitation. We assign dollar values to the production of every metal and mineral exploited in Uruguay: sand, pebble, dolomite, limestone, quartz, feldspar, agate, amethyst, granite, marble, stone slab, clay, talc stone, boulder, iron, loam, sandstone, filita, bentonite, gold minerals, basalt, cornelian, greenstone, granodiorite, fluorite, corundum, coarse, rough stone and conchilla. Mineral prices correspond to the implicit price calculated as the ratio between the production value (BCU website) and our estimates of the physical volume of total production in 2005.

Data for mineral resources before 1957 is not available. In order to obtain the mineral series from 1870 to 1956 , we assume that the evolution of annual mineral income is the same as the mineral value added [ 90 and additional estimates provided by the authors]. The 2004 and 2005 World Bank data on mineral rental rates is a point of reference (World Bank database online); we, however, update upon this by using the ratio of gross operating surplus and value added for use in our model. We use data derived from [107]; we also use other estimates provided by the authors. Finally, we project the mineral rents from 2015 to 2038 assuming that reserves will be exhausted in 25 years.

\subsubsection{Timber Resources}

Timber wealth is computed as the present discounted value of rents from roundwood production. We consider three types of production: coniferous industrial logs, non-coniferous industrial logs and firewood. Also, we consider international trade prices of standing timber for coniferous industrial logs and non-coniferous industrial logs. As there is not international trade in firewood, we estimate the price of firewood price as an average of international prices of coniferous industrial logs and non-coniferous industrial logs.

The time horizon selected to capitalize the annual revenues incorporates the concept of sustainable exploitation. If logging is less than the net annual growth, then the time horizon will be 25 years and the exploitation will be considered sustainable. If annual logging is greater than net increases, it means 
that the holding is not harvested sustainably and therefore the time horizon for the capitalization of annual revenues will be equal to the minimum of 25 and:

$$
\frac{\text { Stock of forest area }(\text { ha }) \times \text { Volume of wood per hectare } \times \text { Forest area available }}{\text { Wood production }- \text { Annual increment }}
$$

The forest area available for timber offer is estimated as forests within $50 \mathrm{~km}$ of infrastructure because not all standing timber is accessible or economically viable.

We use production values from 1870 to 2014 (2005 fixed prices). There is no data for firewood until 1961, so we estimate this production from 1870 to 1960 using the series of firewood consumption from [108].

Also, we apply an annual rental rate in order to obtain annual forest income. For this, we use data derived from [107]; we also use other estimates provided by the authors. The strategy in this case was to consider the rate proposed in [100] (58\%) and for this rate to evolve over time according to the evolution of the ratio between the gross operating surplus and the value added of the activity. This ratio is available for 1997-2005, is considered fixed from 2005 to the present and is historically proxied by the evolution of the inverse ratio of total wages and value added (i.e., considering incomes derived from work in contrast to the incomes derived from capital, in relation to value-added). This ratio is available for 1997-2005, 1958 and 1908 and the rest of the intermediate years are lineal interpolation; for the years before 1908, the level of that year is assumed.

\subsubsection{Non-Timber Forest Resources}

According to specialists from the General Forest Directorate (Dirección General Forestal), only onetwentieth of forest areas in Uruguay are reachable for recreation. Therefore, the per-hectare value for recreation is multiplied by one-twentieth of the stock of forest area to get the benefits of recreation. We use the World Bank reference price, based on [109], of USD 112 per hectare of forest area for that year and adjusted it to 2005 using the USD purchasing power index.

Non-timber wealth is then computed as the present discounted value of rents from non-timber forest benefits. As before, we project the rents from 2015 to 2038 using standard forecasting techniques.

\subsubsection{Protected Areas}

The protected areas (Sistema Nacional de Áreas Protegidas) are valued at the lowest returns per hectare to pasturelands and croplands; this decision implies the interpretation of the price as a quasi-opportunity cost. These returns are then capitalized over a 25 year time horizon. Restricting the value of the protected areas to the opportunity cost of preservation means reflect the minimum but not the entire value of this component.

\subsection{Comparison with Previous Estimates}

As far as we were concerned, the only work that presents a detailed estimate of long-term natural capital is [106]. This historical work puts forward an estimation of natural capital for Sweden for the 19th and 20th centuries. The long-term analysis of this article offers a detailed description of the estimates proposed and its results are an extremely useful point of reference for our research. It shares the methodology of the World Bank but makes some modifications to estimate the value of land dedicated to agriculture. They use the current market price of the land instead of updating the future income of products derived from this kind of asset. The article reports first historical estimates of the $C R I$ and also an estimation of total wealth according to historical surveys and information derived from insurance data. We compare some of our indicators with that data to contrast results. 


\subsection{Contrast with Linear Non-Causality}

As we have already stated, one of the most widespread discussions in the literature has been the relationship between the abundance of natural resources that an economy possesses and the long-term economic evolution that this economy performs. Therefore, our methodological option is to investigate the causal relationships between the two variables.

The fact of having long-term series of natural capital and other variables such as GDP makes it possible to use a concept of specific causality—a la Granger-but taking advantage of techniques which extend upon the standard Granger approach to overcome some of its limitations.

The Toda-Yamamoto (1995) and Dolado-Lütkepohl (1996) test (from now on TYDL) is an extension of the classic linear Granger non-causality test, within the framework of a model of auto-regressive vectors (VAR). Both tests are based on the following operative definition of Granger non-causality.

Let two stationary stochastic processes $\left\{X_{t}\right\},\left\{Y_{t}\right\}$ :

$Y_{t}$ does not Ganger cause $X_{t}$ if $E\left(X_{t}+1 \mid X_{t}\right)=E\left(X_{t}+1 \mid X_{t}, Y_{t}\right)$.

The Granger test has the limitation that it can only be applied for stationary series, so prior to applying it, a series of tests must be done to identify whether unit roots and co-integration are present, in order to afterward make the appropriate transformations to the series. This practice of pre-testing may result in significant over-rejection rates of a null hypothesis of no true causality, finding causal relationships when in fact there are not [110].

The TYDL methodology avoids these preliminary tests and is most useful outside of whatever integration or co-integration may be present in the system, thus obtaining more robust results. It is a parametric test that can be contrasted from linear non-causality.

The TYDL test states that a VAR model $(p+d$ max $)$ must be estimated, where $p$ is the true number of lags of the model (determined by some criterion for selection of lags) and dmax is the maximum order of integration that is suspected to occur in the process.

Next, the last dmax lags are ignored-since, as zeros, they are redundant-and tested the hypothesis of Granger non-causality on the first $p$ lags of the model, using the standard asymptotic theory. The Wald statistic maintains its $\chi^{2}$ distribution below a certain $H_{0}$. If the null hypothesis is rejected, $H_{0}=\beta_{1}=\beta_{2}=, \ldots, \beta_{p}=0$ we can say that the variable $Y$ Granger causes $X$.

\section{Results}

\subsection{Some Stylized Facts}

In this section, we present the main stylized facts based on the estimation of the natural capital series, over 1870-2014, for Uruguay. Our first important result is the estimation of the annual series of natural capital in the long term itself, which makes possible the analysis of its evolution. Over this time period, natural capital grew at an average annual rate of almost $2 \%$ (Table 1), which is less than the average of the entire economy $(3 \%)$, resulting in a sustained decline in its share of GDP (Figure 1b) (Table 1 includes information about three historical sub-periods; see the explanation of this periodization below).

Natural capital is seven times the value of annual GDP at the beginning of the period and even by the WWI, the ratio was around 5 . The only antecedent that is comparable-although information is not available on an annual basis-is the case of Sweden, for which the average over the same period was around 3. Although a broader comparison would be required, this contrast legitimizes to conjecture that Uruguay's historical conceptualization as an economy abundant in natural resources would be correct. In a previous comparison, the two economies were characterized as "resource-rich countries" [111] and Uruguay being comparatively more so when the richness is measured in terms of land. Our evidence is consistent with this last argument.

The long-term evolution of the ratio NK/GDP is an expected result and confirms our first hypothesis. The Uruguayan economy shows growth of GDP per capita throughout the period and this would have been accompanied by a decline in the economic relevance of natural capital in the 
process of generating wealth (which GDP measures). The verification of the hypothesis is indirect because the approach of the World Bank is based on the composition of the total wealth; in any case, the ratio could be a good proxy for the process. The reduction in the ratio was not homogeneous and the evolution involves a trajectory that is consistent with the long-term trajectory of the economy presented in Section 3.

Table 1. Natural capital and GDP.

\begin{tabular}{cccc}
\hline & \multicolumn{2}{c}{ Annual Growth Rates } & \multirow{2}{*}{ NK/GDP } \\
\cline { 2 - 3 } & Natural Capital (NK) & GDP & \\
\hline $1870-1909$ & $2.0 \%$ & $3.6 \%$ & $527.4 \%$ \\
$1910-1959$ & $-0.7 \%$ & $2.8 \%$ & $178.6 \%$ \\
$1960-2014$ & $4.3 \%$ & $2.6 \%$ & $103.5 \%$ \\
$1870-2014$ & $1.9 \%$ & $3.0 \%$ & $133.2 \%$ \\
\hline
\end{tabular}

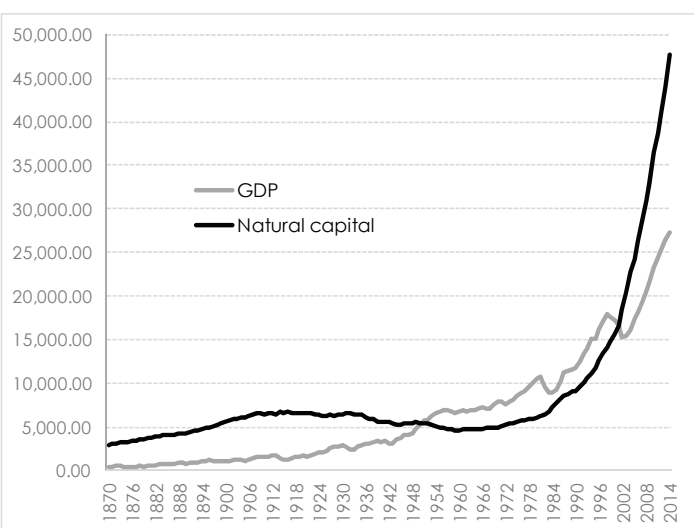

(a)

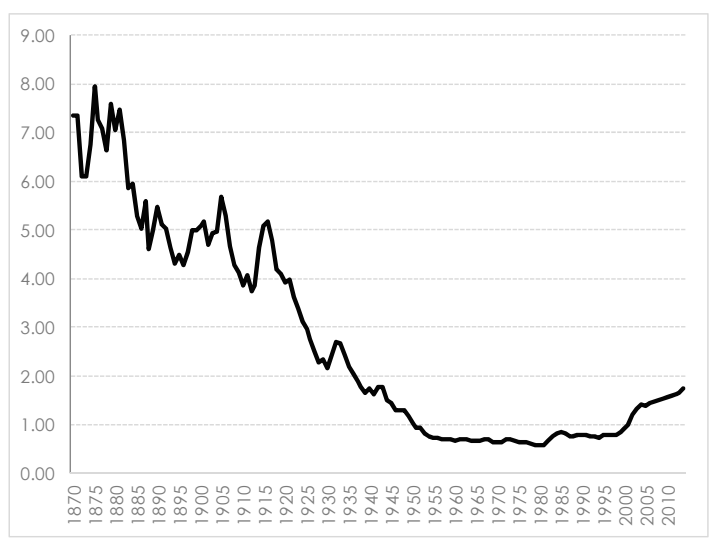

(b)

Figure 1. Natural capital and GDP (2005 million dollars) and NK/GDP ratio. (a) Natural capital and GDP; (b) Natural capital/GDP.

During the First Globalization, natural capital increased continuously and maintained high ratios relative to GDP that averaged 5.5 between 1870 and 1913. It is, in fact, a period in which Uruguay managed to enter in international markets with the export of agricultural commodities and during which expansion of the domestic market occurred at a rate that, in Latin America, only Argentina or Chile could approximate [87]. GDP growth is the highest during this stage (3.6\%), coinciding with the highest levels of NK/GDP ratio (527\%), which leads us to reject the resource curse hypothesis in the case of Uruguay. It is after the WWI when the indicator begins a sustained downward trajectory, a period that different scholars recognize as the beginning of the transition to a new pattern of development [112].

Since the 1930s, the economy experienced an ISI process [92,93], which meant clear signs of structural change and in which activities related to primary production showed clear manifestations of stagnation [113]. It is in this context that total natural capital reaches levels lower than the annual GDP (year 1951), coinciding with the booming period of industrialization. It is only at the end of the 1960s that natural capital begins a progressive recovery (Figure 1a), although, in terms of GDP, the increasing can be seen since the late 1970s, probably due to the commitment to more liberal economic policy and the promotion of non-traditional exports. Nevertheless, it would not be until the 21st century, with a new international boom based on commodities, that natural capital would once again become relevant in the economy, the ratio approaching 2 by 2014. 
From a long-term perspective, the loss of economic relevance of natural capital in the economic structure also meant significant transformations within the natural wealth itself (Figure 2). Three features can be underlined.

First, the increasing diversification of natural capital is notorious. Indeed, whereas in the first decade of the period of analysis land wealth represented $94 \%$ of total natural capital $-85 \%$ corresponding to pastureland and $9 \%$ to croplands-, during the first decade of the 21st century land wealth was still relevant ( $85 \%$ ) but with croplands being the predominant component $(46 \%$ vs. $39 \%)$ and, in addition, forest wealth comprising a significant share (13\%). This broader diversification would have had various linkages with the structural transformation that the economy experienced in various dimensions, both in considering the production structure as a whole [89] and agricultural activity in particular [95] and also the energy matrix itself.

Second, one of the outstanding features of the agricultural sector in Latin America in the last decades of the 20th century was the evidence of the absolute and in particular relative expansion of the sector that has placed the activity on a renewed path of growth [114]. Uruguay has not been an exception to this process, which has involved more intensive production development, with higher requirements for capital, inputs and training $[115,116]$; industrial crops (rice, soybeans) and dairy are the two most evident expressions of this transformation. The strong increase in cropland as a share of natural capital from the 1990s onwards represents this transformation.

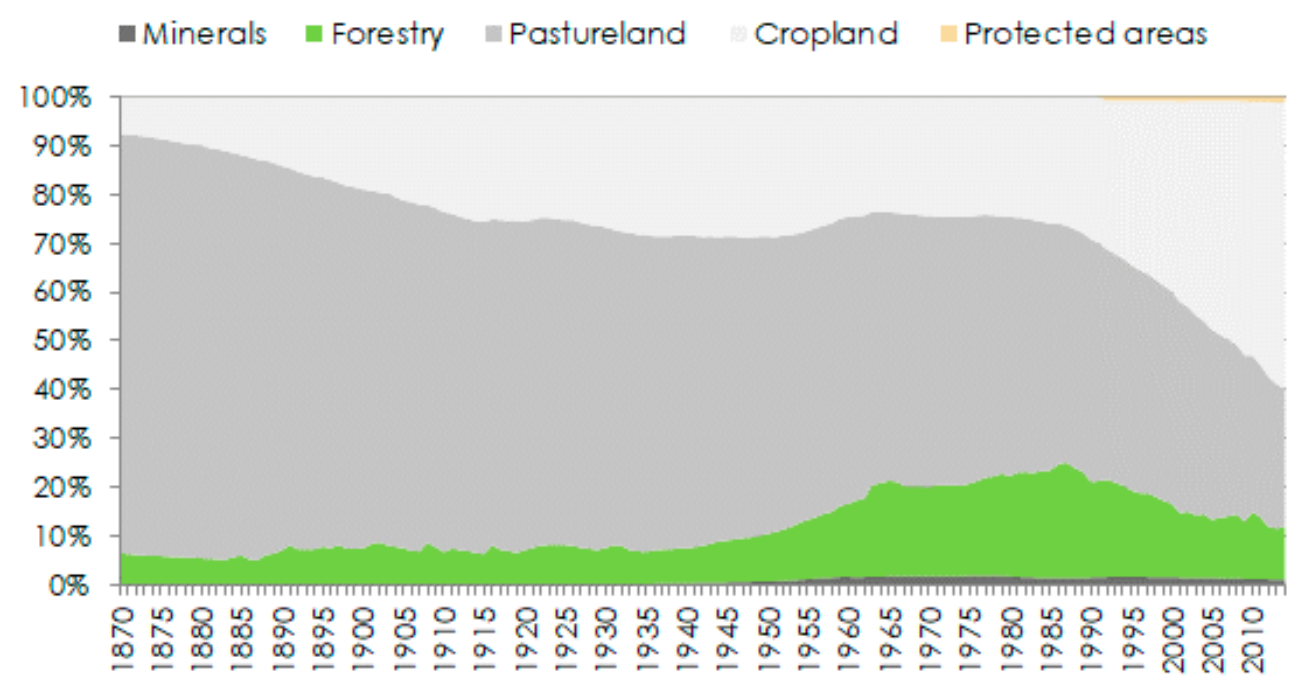

Figure 2. Natural capital shares by component (in percentage).

Third, since the second half of the 20th century, forest wealth is an increasingly important component of Uruguay's natural wealth. Initially, the increase would have had many points of contact with the industrialization process itself since wood was used as a key source of fuel in many manufacturing companies [117]. The changes in the energy matrix that have taken place since the 1980s, decidedly toward hydroelectric generation, presumably underlie the decline observed in the share of this component. However, it is not expectable to return to the levels prior to the expansion due to a combination of, at least, two types of factors. On the one hand, there are legal norms that have offered forestry preferential treatment; on the other hand, the demand for wood for pulp is high in Uruguay and this has sustained production beyond that used for energy.

\subsection{Causality Exercises}

In the previous section, the stylized facts of the long-term evolution of natural capital were presented and it was found to display high consistency with Uruguayan economic history. However, these assessments do not respond to whether the relationship between natural capital and 
economic performance is causal. In this section, some standard statistical causality exercises are presented as a first approximation on this matter.

To start with, causality exercises are proposed between the growth rates of natural capital and GDP for the entire period of analysis, with no evidence of Granger causality in either direction (Table 2) (a $p$-value below the 5\% significance level indicates rejection of the null hypothesis of non-causality between natural capital and GDP and vice versa). However, judging by the evolution of the variables, it is possible to expect the relationship to change over time and so the period was partitioned. The statistical exercise is sensitive to the length and the extremes of the period, on which many tests were carried, out and we have decided to apply a periodization representative of development patterns discussed above: the agro-export period (1870-1909); the end of the previous pattern and ISI (1910-1959); the end of the previous pattern and liberalization and promotion of non-traditional exports (1960-2014). In addition to the identification of historical periods, we try to divide our 144 years into 50-year windows to compare periods of similar duration.

Table 2. Results of the non-causality test of TYDL between NK and GDP.

\begin{tabular}{ccccc}
\hline \multirow{2}{*}{ Period } & \multicolumn{2}{c}{$\mathbf{H}_{\mathbf{0}}$ : $\mathbf{l n}$ NK Does Not Cause lnGDP } & \multicolumn{2}{c}{$\mathbf{H}_{\mathbf{0}}: \ln$ GDP Does Not Cause lnNK } \\
\cline { 2 - 5 } & $\chi^{2}$ Statistic & $\boldsymbol{p}$-Value & $\chi^{2}$ Statistic & $p$-Value \\
\hline $1870-1909$ & 0.39 & 0.531 & 2.56 & 0.109 \\
$1910-1959$ & 0.26 & 0.607 & 0.07 & 0.790 \\
$1960-2014$ & 2.13 & 0.346 & 7.95 & 0.047 \\
$1870-2014$ & 1.44 & 0.837 & 4.45 & 0.348 \\
\hline
\end{tabular}

As is shown in Table 2, none of the tests allow to reject the null hypothesis of non-causality in either direction with the only exception of the last sub-period (1960-2014), for causality from GDP to natural capital.

In consideration of the previous results and the evidence found in other works referring to the fact that it is important to identify natural capital action channels rather than the direct impact of this on GDP, additional exercises are proposed. Using the classification of the explanatory factors of economic growth in terms of proximate, intermediate and ultimate causes [118-121], we choose to work only with the first. The ultimate and deepest causes of growth and economic development-geographic conditions, institutions, power and long-run development in science and technology-deserve special treatment that exceeds the objectives of this article.

To represent the proximate and intermediate factors of economic growth, we propose to work with two typical factors of supply (physical or produced capital and human capital; the data come from [122,123]) and demand (exports and terms of trade; the data come from [124]) to cover "both sides" of the market. The results are presented in Tables 3 and 4 considering, respectively, the causality from each factor to natural capital and vice versa (exercises for the entire period are not reported; in all cases the hypothesis of non-causality is not rejected).

Table 3. Results of the TYDL statistic non-causality test from produced capital, human capital, exports and terms of trade to natural capital.

\begin{tabular}{ccccccc}
\hline & \multicolumn{2}{c}{$\mathbf{1 8 7 0 - 1 9 0 9}$} & \multicolumn{2}{c}{$\mathbf{1 9 1 0 - 1 9 5 9}$} & \multicolumn{2}{c}{$\mathbf{1 9 6 0 - 2 0 1 4}$} \\
\cline { 2 - 7 } & Statistic & $\boldsymbol{p}$-Value & Statistic & $\boldsymbol{p}$-Value & Statistic & $\boldsymbol{p}$-Value \\
\hline Produced capital & 11.13 & 0.004 & 0.36 & 0.947 & 3.51 & 0.173 \\
Human capital & 0.40 & 0.525 & 9.86 & 0.043 & 2.67 & 0.102 \\
Exports & 0.63 & 0.429 & 7.76 & 0.021 & 0.76 & 0.385 \\
Terms of trade & 8.65 & 0.033 & 0.00 & 0.985 & 3.09 & 0.079 \\
\hline
\end{tabular}


Table 4. Results of the TYDL non-causality test from natural capital to produced capital, human capital, exports and terms of trade.

\begin{tabular}{ccccccc}
\hline & \multicolumn{2}{c}{$\mathbf{1 8 7 0 - 1 9 0 9}$} & \multicolumn{2}{c}{$\mathbf{1 9 1 0 - 1 9 5 9}$} & \multicolumn{2}{c}{$\mathbf{1 9 6 0 - 2 0 1 4}$} \\
\cline { 2 - 7 } & Statistic & $\boldsymbol{p}$-Value & Statistic & $\boldsymbol{p}$-Value & Statistic & $\boldsymbol{p}$-Value \\
\hline Produced capital & 2.6 & 0.273 & 3.35 & 0.340 & 0.62 & 0.733 \\
Human capital & 0.44 & 0.506 & 8.41 & 0.078 & 0.27 & 0.600 \\
Exports & 0.96 & 0.328 & 3.04 & 0.219 & 1.44 & 0.229 \\
Terms of trade & 0.9 & 0.342 & 0.94 & 0.331 & 0.83 & 0.364 \\
\hline
\end{tabular}

As shown in Table 3, in the 1870-1909 period, both produced capital and terms of trade cause natural capital. Both results were expected. On the one hand, the increasing trajectory of the investment during the last two decades of the 19th century "seems ... related to the creation of conditions to support the 'take-off' of the agro-exporter economy" [122] such as in the form of railways, harbors and roads. In these terms, the natural capital would have been endogenous to the physical capital at least in the initial stages of the expansion. On the other hand, this period was characterized by strong growth in the prices of exported goods $[125,126]$, in particular of primary sector origin, which would have encouraged the expansion of the natural capital.

The second period was a phase of decreasing of natural capital in real terms (Table 1) and so human capital and exports both cause the natural asset. In the case of human capital, the result is consistent with an important expansion of the social public expenditure in education $[127,128]$ and in particular the extension of the construction of school along the national territory [128]. Our interpretation of this process corroborates the expectation of the World Bank about the evolution of the composition of total wealth in the long run. According to [100]—in the tradition of "weak sustainability" —one of the stylized facts of economic growth is the substitution of natural capital by other types of assets, in particular human and intangible capital. Our evidence is consistent with this argument. Since neither physical capital nor human capital were displaced by natural capital, our evidence contradicts arguments in the tradition of the crowding-out approach presented above.

In the case of exports, the regulations, norms and, in general, the economic policy of the period, meant an inward looking development [92] that severely affected the export capacity of the economy [129]. Considering that most of the exports originated from agricultural commodities, the adverse consequences on the formation of natural capital would have been inevitable. Natural capital did not block the structural change but several factors that promoted industrialization affected exports, thereby reducing the relative abundance of natural resources.

Finally, in the third period, when the economy advanced through a progressive process of outward economic orientation, liberalization and openness, we find the terms of trade to once again be decisive in the growth of natural capital (if we allow a $10 \%$ significance level).

We repeat the exercises but considering the inverse causality. The results, presented in Table 4, show that natural capital does not cause the factors considered, with the only exception of human capital, in the second period ( $10 \%$ significance).

\section{Discussion}

One of the main arguments of the economic history approach presented in Section 2 is that "rather than being a general pattern, the curse seems subject to the influence of supply and demand conditions, technological progress and institutional structure with strong historical specificities" [130] (p. 248). Our long-term analysis provides an adequate framework to analyze how the relationships change over time and how difficult it can become to sustain the "curse"—or the "blessing"—as an immutable hypothesis.

Our first result is that natural capital has tended to decline in importance to the economy (measured as the ratio of natural capital and GDP). This is a historically consistent result. The economic 
transformation from a model based on agro-exports to another where the driver of the economy was industrialization - until the end of the 1950s-meant declining influence of natural capital on the internal generation of incomes. The conditions of the model began to change from the 1970s onwards and, especially with the commodity-boom of the 21st century, natural capital has become more economically relevant again in the case of Uruguay. Additionally, our result constitutes indirect evidence of the assertion of [100] about the share of natural capital being a smaller share of total wealth in more developed economies. This evidence is indirect for two reasons. On the one hand, the approach of the World Bank refers to cross-sectional evidence, i.e., comparisons between economies with different levels of development at the same time. However, in our case we consider one country that increased its economic development and wellbeing in the long run. The approach of the World Bank refers to shares of wealth whereas our estimates refer to shares of GDP.

Our second result is to identify an important long-run diversification of the natural capital since the second half of the 20th century. This evolution expresses the dual impact of a remarkable process of change in the agricultural production, based on the intensive use of factors with intensive production (industrial crops such as rice and soybeans, as well as dairy industry) comprising a larger share of the subsector and the rising presence of forestry in the use of land.

Our third result refers to the causality relationships; for these exercises, we consider the entire period and three sub periods: 1870-1909, 1910-1959 and 1960-2014. We do not find causal relations between the increase in natural capital and economic growth in the long run nor in the sub-periods, with only one exception (from economic growth to growth in natural capital for 1960-2014). In other words, we do not find evidence to confirm the presence of a curse or blessing of natural resource abundance. The evolution of the natural capital does not influence economic growth in the long run. We thus consider several channels (see Section 2, crowding-out approach) that, potentially, may connect the two processes. Our stronger evidence shows that proximate and intermediate explanatory variables for economic growth cause changes in natural capital (with significance varying by sub-period). We interpret these results according to theoretical positions that conceptualize the abundance of natural resources as an endogenous process (see Section 2, economic history approach).

\section{Conclusions}

The debate on the link between natural resources abundance and economic growth is still open. Our contribution to this field consider a long-run approach (that covers the period 1870-2014) with the analysis of a periphery country of the world economy-Uruguay-that has three features that make it an interesting case: (i) the "internal" economy shows evidence of structural change but the exports have remained highly concentrated in primary products (we identify this process with the idea of duality of the structural change); (ii) it is, historically, a natural resources abundant economy intensively positioned in renewable resources (in contrast with most extended analyses in the field that focus, mainly, on non-renewable resources); (iii) the availability of information makes it possible to compute using estimations of natural capital over a very long time frame.

The objective is to construct historical series of natural capital based on the World Bank methodology. This methodology rests on the well-established economic principle that valuation of assets should be calculated according to the present discounted value of economic rents (or profits) over the life horizon of the resource. We contrast the level and evolution of the natural capital with the level and growth of GDP, as well as the proximate and intermediate causes of economic growth (produced and human capital, exports, terms of trade).

We show that natural capital tends to reduce its importance on the economy and, simultaneously, increases its diversification. Although this evolution is consistent in historical terms, we do not find a causal relationship between the abundance of natural resources and economic growth. Instead of a direct relationship, the proximate and intermediate causes appear to be important in explaining the evolution of natural capital when we consider three stages of economic growth: physical capital and terms of trade during the agro-exporter model, human capital and exports during the period of import 
substitution industrialization and terms of trade from the 1960s afterwards. These factors cause the growth of natural capital but not the other way around, which leads us to conclude that abundance of natural capital is an endogenous process.

In other words, natural capital is not just a matter of endowment. Blessings or curses are "created" by the effects of multiple factors, which change over time and go hand in hand with the economic transformation that structural change implies. This notion is not new. "Resources are highly dynamic concepts; they are not, they become, they evolve out of the triune interaction of nature, man and culture ..." (Quoted in [131], p. 14, from a book of Erich Zimmerman of 1933). Natural resources "should not be seen as merely a fortunate natural endowment but rather as a form of collective learning" [132] (p. 186) and also as a return on investments, transportation, knowledge and the technologies of natural exploitation. Our research has considered only some factors that can affect this process and our evidence supports the inclusion of additional aspects such as technological and institutional issues in the future.

Supplementary Materials: The following are available online at http:/ / www.mdpi.com/2071-1050/10/3/715/s1, Assumptions and sources.

Acknowledgments: We would like to thank Reto Bertoni and Luis Bértola for their comments and contributions, and Carolina Román and Sabrina Siniscalchi who read our work and shared their knowledge. Thanks to Nicolás Bonino, Bibiana Lanzilotta and Paola Azar for their help with econometric exercises and to Inés Moraes and Pablo Castro for answering successive questions about sources. We are grateful to DINAMIGE, Dirección General Forestal, Dardo Fagundez of OPYPA and to the World Bank also for responding to our doubts. We bear sole responsibility for any errors that remain. We did not receive additional funding sources in the preparation of this work or in its publication.

Author Contributions: Henry Willebald designed the research, Silvana Sandonato performed the research and both authors analyzed the data and wrote the paper. Both authors read and approved the final manuscript.

Conflicts of Interest: The authors declare no conflict of interest.

\section{Appendix. Measuring the Consumption Rate of Interest}

In order to calculate total wealth, it is necessary an adequate estimation of the social time preference rate or consumption rate of interest (CRI). CRI is the rate at which the marginal welfare of consumption decreases over time. It is usually applied in cost-benefit analyses and environmental economics (see [133] for a general discussion).

CRI estimate is based on the methodology proposed in [105] and, fundamentally, the decisions adopted in $[106,134]$. Our basic components are the following:

- $\quad \rho=$ pure time preference.

- $L=$ changing life chance (negative sign).

- $\mu=$ marginal utility of consumption.

- $g=$ expected growth rate of consumption.

According to these definitions, we calculate the CRI as:

$$
C R I=\rho-L+(\mu g)
$$

$\rho$ cannot be observed historically and a constant time preference-and equal to $0.3 \%$ (according to [104])—is assumed over the full period of analysis.

$\mu$ is given by:

$$
\mu=\frac{r-\rho}{\frac{S}{Y}(r-y)+y}
$$

where:

$S / Y$ : investment ratio,

$r$ : expected rate of return on investment, 
$y$ : expected growth rate of incomes from work.

To estimate the marginal utility of consumption, several considerations are required.

First of all, $S / Y$ is the savings ratio and is calculated from historical national accounts for Uruguay. $Y$ is GDP and $S$ the difference between GDP and total consumption; all data are derived from [124]; we use items in current prices.

Second, following [106], $y$ is the expected growth rate in incomes from work and it is calculated as the growth rate of total wages $(\mathrm{W})$. $\mathrm{W}$ is also adjusted for change in consumption prices. We suppose that expected growth rates are entirely based on the history of the variable. Therefore, we calculated a stochastic but smooth trend in a structural time series framework. The slope of the trend in each year represents the long-run expected growth rate of wages. This decision implies, implicitly, to suppose that cyclical and irregular items of the time series correspond to business cycle phenomenon and did not affect the expectations of the economic agents. Considering $r$, we observe that it is conceptually similar to the expected growth rate of capital incomes. We measure $r$ similarly to $y$ but in this case estimating the growth rate of gross profits $(Y-W)$. Data were derived from [107] and elaborations of the authors.

$L$ represents that if possibilities for a long life are scarce, then a high interest rate is required to motivate certain levels of savings. In empirical terms, $L$ is the "crude death rate": $L=-$ (Total deaths/ Total population). Data were collected from Uruguayan vital statistics (1900-2014: Instituto de Estadistica (online); 1870-1899: Statistical Yearbooks (1899-1900) and authors' estimates).

Finally, $g$ is the long-term growth rate of consumption. Information derived from historical national accounts presented in [124] and, as before, we estimated a stochastic but smooth trend in a structural time series framework where the slope of the trend in a given year is understood as the long-term expected growth rate.

The $C R I$ is a rate to reflect society's willingness to give up a unit of current consumption in exchange for more in future consumption [135]. This rate can be used as a social discount rate as is demonstrated in $[136,137]$. Social time preference rate is different to the individual time preference. The reason is individual time preference rates are revealed from the market decisions, such as lending and borrowing rates according to the current real interest rate. However, the decision of society's willingness to trade off consumption now for later is not solely based on the market but also other factors. Therefore, the CRI is not equivalent to individual time preference. The manner in which society is valuing the future depends on multiple factors as individual time preference, life expectancy, expected incomes of the different social classes and the expectations related to the evolution of future consumption.

In the case of Uruguay, the evolution of the CRI (Figure A1) presents a changing trajectory that indicates the historic transformation of a "successful" society to another with huge doubts about the future. This change was especially evident from the beginning of the second half of the 20th century when the industrialization process exhausted and inflation started spiraled upward [138]. Referring to this period, ([139] (p. 82-83), our translation) states:

"In a small economy which is susceptible to face major external shocks given its fragile international trade relations, the inefficacy of the macroeconomic policy to stabilize the economy caused very pronounced cyclical fluctuations. Therefore, even though the economy grows, deep crises reverse some achievements obtained during the boom periods. Within this context, uncertainty increases and investment decisions are made on a reduced time horizon with expectation of extraordinarily high returns. In the case of Uruguay, these crisis episodes occur quite often and affect the agent's behavior which becomes more impatient and, therefore, less willing to invest in long-term projects, innovate, develop or incorporate technology." 


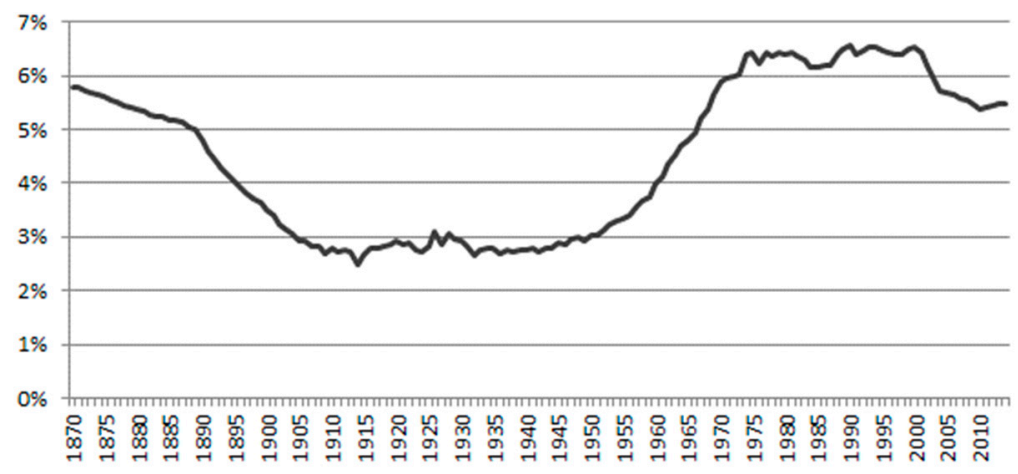

Figure A1. The consumption rate of interest in Uruguay, 1870-2014. Source: developed by authors.

\section{References}

1. Sachs, J. How to handle the macroeconomics of oil wealth. In Escaping the Resource Curse; Humphreys, M., Sachs, J., Stiglitz, J., Eds.; Columbia University Press: New York, NY, USA, 2007; pp. 173-193.

2. Badeeb, R.; Lean, H.; Clark, J. The evolution of the natural resource curse thesis: A critical literature survey. Resour. Policy 2017, 51, 123-134. [CrossRef]

3. Auty, R. Sustaining Development in Mineral Economies: The Resource Curse Thesis; Routledge: London, UK, 1993.

4. Manzano, O.; Rigobon, R. Resource Curse of Debt Overhang? National Bureau of Economic Research: Cambridge, MA, USA, 2001; pp. 1-37.

5. Leite, C.; Weidmann, J. Does Mother Nature Corrupt? Natural Resources, Corruption and Economic Growth; International Monetary Fund: Washington, DC, USA, 1999.

6. Van der Ploeg, F. Natural resources: Curse or blessing? J. Econ. Lit. 2011, 49, 366-420. [CrossRef]

7. Torvik, R. Why do some resource-abundant countries succeed while others do not? Oxf. Rev. Econ. Policy 2009, 25, 241-256. [CrossRef]

8. Willebald, H.; Badía-Miró, M.; Pinilla, V. Introduction: Natural resources and economic development. What can we learn from history? In Natural Resources and Economic Growth: Learning from History; Badía-Miró, M., Pinilla, V., Willebald, H., Eds.; Routledge Explorations in Economic History; Taylor \& Francis Group: London, UK; New York, NY, USA, 2015; pp. 21-45.

9. Barbier, E. Frontier expansion and economic development. Contemp. Econ. Policy 2005, 23, 165-316. [CrossRef]

10. David, P.; Wright, G. Increasing returns and the genesis of American resource abundance. Ind. Corp. Chang. 1997, 6, 203-245. [CrossRef]

11. Wright, G. Resource-based growth then and now. In Patterns of Integration in the Global Economy; World Bank Project, Ed.; World Bank: Washington, DC, USA, 2001.

12. Cimoli, M.; Porcile, G.; Primi, A.; Vergara, S. Cambio estructural, heterogeneidad productiva y tecnología en América Latina. In Heterogeneidad Estructural, Asimetrías Tecnológicas y Crecimiento en América Latina; Cimoli, M., Ed.; CEPAL-BID: Santiago de Chile, Chile, 2005; pp. 9-39.

13. Presbich, R. El desarrollo económico de la América Latina y algunos de sus principales problemas. El Trimest. Econ. 1949, 16, 347-431.

14. Singer, $\mathrm{H}$. The distribution of gains between investing and borrowing countries. Am. Econ. Rev. 1950, 40, 473-485.

15. Seers, D. A model of comparative rates of growth in the world economy. Econ. J. 1962, 72, 45-78. [CrossRef]

16. McCombie, J.; Roberts, M. The role of the balance of payments in economic growth. In The Economics of Demand-Led Growth. Challenging the Supply-Side Vision of the Long Run; Setterfield, M., Ed.; Wiley: Hoboken, NJ, USA, 2002; pp. 87-114.

17. Dosi, G.; Nelson, R. Technical change and industrial dynamics as evolutionary processes. In Handbook of the Economics of Innovation; Hall, B., Rosenberg, N., Eds.; North Holland: Amsterdam, The Netherlands, 2010; pp. 51-127.

18. Corden, W.; Neary, J. Booming sector and de-industrialization in a small open economy. Econ. J. 1982, 92, 825-848. [CrossRef] 
19. Corden, W. Booming sector and Dutch disease economics: Survey and consolidation. Oxf. Econ. Pap. 1984, 36, 359-380. [CrossRef]

20. Neary, J.; van Wijnbergen, S. Natural Resources and the Macroeconomy; MIT Press: Cambridge, MA, USA, 1986.

21. Gylfason, T. Natural resources and economic growth: From dependence to diversification. In Economic Liberalization and Integration Policy: Options for Eastern Europe and Russia; Broadman, H.G., Paas, T., Welfens, P.J.J., Eds.; Springer: Berlín, Germany, 2006.

22. Sachs, J.; Warner, A. The curse of natural resources. Eur. Econ. Rev. 2001, 45, 827-838. [CrossRef]

23. Auty, R. Introduction and Overview. In Resource Abundance and Economic Development; Auty, R., Ed.; Oxford University Press: Oxford, UK, 2001; pp. 3-18.

24. Bulte, E.; Damania, R.; Deacon, R. Resource intensity, institutions, and development. World Dev. 2005, 33, 1029-1044. [CrossRef]

25. Sala-i-Martin, X.; Subramanian, A. Addressing the natural resource curse: An illustration from Nigeria. J. Afr. Econ. 2013, 22, 570-615. [CrossRef]

26. Auty, R. The political economy of resource-driven growth. Eur. Econ. Rev. 2001, 45, 839-846. [CrossRef]

27. Isham, J.; Woolcock, M.; Pritchett, L.; Busby, G. The varieties of resource experience: Natural resource export structures and the political economy of economic growth. World Bank Econ. Rev. 2005, 19, 141-174. [CrossRef]

28. Woolcock, M.; Prichett, L.; Isham, J. The social foundations of poor economic growth in resource-rich economies. In Resource Abundance and Economic Development; Oxford University Press: New York, NY, USA, 2001.

29. Boschini, A.; Pettersson, J.; Roine, J. Resource curse or not: A question of appropriability. Scand. J. Econ. 2007, 109, 593-617. [CrossRef]

30. Birdsall, N.; Pinckney, T.; Sabot, R. Natural Resources, Human Capital, and Growth; Carnegie Endowment for International Peace: Washington, DC, USA, 2000.

31. Wood, A.; Mayer, J. Africa's export structure in a comparative perspective. Camb. J. Econ. 2001, 25, 369-394. [CrossRef]

32. Bravo, C.; De Gregorio, J. The Relative Richness of the Poor? Natural Resources, Human Capital and Economic Growth; The World Bank Policy Research; World Bank: Washington, DC, USA, 2005.

33. Barbier, E. Scarcity, frontiers and the resource curse: A historical perspective. In Natural Resources and Economic Growth: Learning from History; Badía-Miró, M., Pinilla, V., Willebald, H., Eds.; Routledge Explorations in Economic History; Taylor \& Francis Group: London, UK; New York, NY, USA, 2015; pp. 54-76.

34. Acemoglu, D.; Johnson, S.; Robinson, J. The colonial origins of comparative development: An empirical Investigation. Am. Econ. Rev. 2001, 91, 1369-1401. [CrossRef]

35. Engerman, S.; Sokoloff, K. Factor endowments, institutions, and differential paths of growth among new world economies. In How Latin America Fell Behind: Essays on the Economic Histories of Brazil and Mexico; Haber, S., Ed.; Stanford University Press: Stanford, CA, USA, 1997; pp. 260-304.

36. Engerman, S.; Sokoloff, K. Factor Endowments, Inequality, and Paths of Development among New World Economies; National Bureau of Economic Research: Cambridge, MA, USA, 2002.

37. Gelb, A.H. Oil Windfalls: Blessing or Curse? Cambridge University Press: New York, NY, USA, 1998.

38. Sachs, J.; Warner, A. Natural Resource Abundance and Economic Growth; National Bureau of Economic Research: Cambridge, MA, USA, 1995.

39. Neumayer, E. Does the "resource curse" hold for growth in genuine income as well? World Dev. 2004, 32, 1627-1640. [CrossRef]

40. Arezki, R.; Van der Ploeg, F. Can the Natural Resource Curse be turned into a Blessing? The Role of Trade Policies and Institutions; International Monetary Fund: Washington, DC, USA, 2011.

41. Beck, T. Finance and Oil: Is There a Resource Curse in Financial Development? Available online: https://papers. ssrn.com/sol3/papers.cfm?abstract_id=1769803 (accessed on 20 February 2018).

42. Boschini, A.; Pettersson, J.; Roine, J. The resource curse and its potential reversal. World Dev. 2013, 43, $19-41$. [CrossRef]

43. Ross, M. A closer look at oil, diamonds, and civil war. Annu. Rev. Political Sci. 2006, 9, 265-300. [CrossRef]

44. Auty, R. The resource curse and sustainable development. In Handbook of Sustainable Development; Atkinson, G., Dietz, S., Neumayer, E., Eds.; Edward Elgar: Cheltenham, UK, 2007; pp. 207-219.

45. Collier, P.; Hoeffler, A. Testing the neocon agenda: Democracy in resource-rich societies. Eur. Econ. Rev. 2009, 53, 293-308. [CrossRef] 
46. Boos, A.; Holm-Müller, K. The relationship between the resource curse and genuine savings: Empirical evidence. J. Sustain. Dev. 2013, 6, 59-72. [CrossRef]

47. Bhattacharyya, S.; Hodler, R. Do Natural Resource Revenues Hinder Financial Development? The Role of Political Institutions; Oxford Centre for the Analysis of Resource Rich Economies: Oxford, UK, 2014.

48. Bhattacharyya, S.; Collier, P. Public Capital in Resource Rich Economies: Is there a Curse? Center for the Study of African Economies: Oxford, UK, 2014.

49. Gylfason, T. Nature, power and growth. Scott. J. Political Econ. 2001, 48, 558-588. [CrossRef]

50. Dietz, S.; Neumayer, E.; De Soysa, I. Corruption, the resource curse and genuine saving. Environ. Dev. Econ. 2007, 12, 33-53. [CrossRef]

51. Barajas, M.; Chami, M.; Yousefi, M. The Finance and Growth Nexus Re-Examined: Do All Countries Benefit Equally? International Monetary Fund: Washington, DC, USA, 2013.

52. Daniele, V. Natural resources and the 'quality'of economic development. J. Dev. Stud. 2011, 47, 545-573. [CrossRef]

53. Stijns, J. Natural resource abundance and economic growth revisited. Resour. Policy 2005, 30, 107-130. [CrossRef]

54. Brunnschweiler, C. Cursing the blessings? Natural resource abundance, institutions, and economic growth. World Dev. 2008, 36, 399-419. [CrossRef]

55. Brunnschweiler, C.; Bulte, E. The resource curse revisited and revised: A tale of paradoxes and red herrings. J. Environ. Econ. Manag. 2008, 55, 248-264. [CrossRef]

56. Dartey-Baah, K.; Amponsah-Tawiah, K.; Aratuo, D. Emerging "Dutch disease" in emerging oil economy: Ghana's perspective. Soc. Bus. Rev. 2012, 7, 185-199. [CrossRef]

57. Papyrakis, E.; Gerlagh, R. Resource abundance and economic growth in the United States. Eur. Econ. Rev. 2007, 51, 1011-1039. [CrossRef]

58. Pegg, S. Is there a Dutch disease in Botswana? Resour. Policy 2010, 35, 14-19. [CrossRef]

59. Fosu, A.; Gyapong, A. Terms of trade and growth of resource economies: Contrasting evidence from two African countries. In Beyond the Curse: Policies to Harness the Power of Natural Resources; Arezki, R., Gylfason, T., Sy, A., Eds.; International Monetary Fund: Washington, DC, USA, 2011; pp. 257-272.

60. De Gregorio, J.; Labbé, F. Copper, The real exchange rate and macroeconomic fluctuations in Chile. In Beyond the Curse: Policies to Harness the Power of Natural Resources; Arezki, R., Gylfason, T., Sy, A., Eds.; International Monetary Fund: Washington, DC, USA, 2011; pp. 203-233.

61. Gylfason, T. Natural Resource Endowment: A Mixed Blessing? Available online: https://papers.ssrn.com/ sol3/papers.cfm?abstract_id=1766385 (accessed on 20 February 2018).

62. Loayza, N.; Mier y Teran, A.; Rigolini, J. Poverty, Inequality, and the Local Natural Resource Curse; World Bank, Policy Research Working Paper; World Bank: Washington, DC, USA, 2013.

63. Liu, Y. Is the natural resource production a blessing or curse for China's urbanization? Evidence from a space-time panel data model. Econ. Model. 2014, 38, 404-416. [CrossRef]

64. Hammond, J. The resource curse and oil revenues in Angola and Venezuela. Sci. Soc. 2011, 75, 348-378. [CrossRef]

65. Rubio, M. Oil illusion and delusion: Mexico and Venezuela over the twentieth century. In Natural Resources and Economic Growth: Learning from History; Badía-Miró, M., Pinilla, V., Willebald, H., Eds.; Routledge Explorations in Economic History; Taylor \& Francis Group: London, UK; New York, NY, USA, 2015; pp. 160-183.

66. Marwah, H. Oil as sweet as honey: Linking natural resources, government institutions and domestic capital investment in Nigeria 1960-2000. In Natural Resources and Economic Growth: Learning from History; Badía-Miró, M., Pinilla, V., Willebald, H., Eds.; Routledge Explorations in Economic History; Taylor \& Francis Group: London, UK; New York, NY, USA, 2015; pp. 100-118.

67. Stijns, J. Natural resource abundance and human capital accumulation. World Dev. 2006, 34, 1060-1083. [CrossRef]

68. Blanco, L.; Grier, R. Natural resource dependence and the accumulation of physical and human capital in Latin America. Resour. Policy 2012, 37, 281-295. [CrossRef]

69. Shao, S.; Yang, L. Natural resource dependence, human capital accumulation, and economic growth: A combined explanation for the resource curse and the resource blessing. Energy Policy 2014, 74, 632-642. [CrossRef] 
70. Atkinson, G.; Hamilton, K. Savings, growth and the resource curse hypothesis. World Dev. 2003, 31, $1793-1801$. [CrossRef]

71. Wood, A.; Berge, K. Exporting manufactures: Human resources, Natural Resources, and Trade Policy. J. Dev. Stud. 1997, 34, 35-59. [CrossRef]

72. Bornhorst, F.; Thornton, J.; Gupta, S. Natural Resource Endowments, Governance, and the Domestic Revenue Effort: Evidence from a Panel of Countries; International Monetary Fund: Washington, DC, USA, 2008.

73. Mehlum, H.; Moene, K.; Torvik, R. Institutions and the resource curse. Econ. J. 2006, 116, 1-20. [CrossRef]

74. Alexeev, M.; Conrad, R. The elusive curse of oil. Rev. Econ. Stat. 2009, 91, 586-598. [CrossRef]

75. Lederman, D.; Maloney, W. Natural Resources: Neither Curse nor Destiny; The World Bank: Washington, DC, USA, 2007.

76. Boyce, J.; Herbert Emery, J. Is a negative correlation between resource abundance and growth sufficient evidence that there is a "resource curse"? Resour. Policy 2011, 36, 1-13. [CrossRef]

77. Cavalcanti, T.; Mohaddes, K.; Raissi, M. Growth, development and natural resources: New evidence using a heterogeneous panel analysis. Q. Rev. Econ. Finance 2011, 51, 305-318. [CrossRef]

78. James, A. The resource curse: A statistical mirage? J. Dev. Econ. 2015, 114, 55-63. [CrossRef]

79. Auty, R. From resource cruse to rent curse: A theoretical perspective. In Natural Resources and Economic Growth: Learning from History; Badía-Miró, M., Pinilla, V., Willebald, H., Eds.; Routledge Explorations in Economic History; Taylor \& Francis Group: London, UK; New York, NY, USA, 2015.

80. Lewis, W. Crecimiento y Fluctuaciones; Fundación de Cultura Económica: Buenos Aires, Argentina, 1983; p. 209.

81. Foreman-Peck, J. A History of the World Economy. International Economic Relations since 1850; Harvester Press: Brighton, UK, 1983.

82. Álvarez, J.; Bilancini, E.; D'Alessandro, S.; Porcile, G. Agricultural institutions, industrialization and growth: The case of New Zealand and Uruguay in 1870-1940. Explor. Econ. Hist. 2011, 48, 151-168. [CrossRef]

83. Willebald, H.; Bértola, L. Uneven development paths among Settler Societies, 1870-2000. In Settler Economies in World History; Lloyd, C., Metzer, J., Sutch, R., Eds.; Brill: Leiden, The Netherlands, 2013; pp. 105-140.

84. Wellstead, A. The (post) staples economy and the (post) staples state in historical perspective. Can. Political Sci. Rev. 2007, 1, 8-25.

85. Bértola, L. Overview of the Economic History of Uruguay Since the 1870s. Available online: http:/ / eh.net/ encyclopedia/article/Bertola.Uruguay.final (accessed on 20 February 2018).

86. Oddone, G. El Declive. Una Mirada de la Economía de Uruguay en el Siglo XX; Librería Linardi y Risso: Montevideo, Uruguay, 2010.

87. Bulmer-Thomas, V. The Economic History of Latin America since Independence; Cambridge University Press: Cambridge, UK, 2003.

88. Bonino, N.; Tena, A.; Willebald, H. Uruguay and the first globalization: On the accuracy of export performance, 1870-1913. Rev. Hist. Econ. 2015, 33, 287-320.

89. Willebald, H. Desigualdad y especialización en el crecimiento de las economías templadas de nuevo asentamiento, 1870-1940. Rev. Hist. Econ. 2007, 25, 293-348. [CrossRef]

90. Bonino, N.; Román, C.; Willebald, H. Structural change and long-term patterns. A methodological proposal for Uruguay in the very long run. In Proceedings of the Seminario de Investigación, Programa de Historia Económica y Social, PHES-FCS-UdelaR, Montevideo, Uruguay, 6 September 2012.

91. Jacob, R. Uruguay 1929-1938: Depresión Ganadera y Desarrollo Fabril; Fundación de Cultura Universitaria: Montevideo, Uruguay, 1981; p. 432.

92. Bértola, L. La Industria Manufacturera Uruguaya 1913-1961: Un Enfoque Sectorial de su Crecimiento, Fluctuaciones y Crisis; Facultad de Ciencias Sociales de la Universidad de la República y Centro Interdisciplinario de Estudios sobre el Desarrollo Uruguay: Montevideo, Uruguay, 1993.

93. Arnabal, L.; Bertino, M.; Fleitas, S. Una revisión Del desempeño de la industria en Uruguay entre 1930 y 1959. Rev. Hist. Ind. 2013, 13, 143-173.

94. Astori, D. Estancamiento, desequilibrios y ruptura. 1955-1972. In El Uruguay Del Siglo XX; Instituto de Economía, Ed.; Ediciones de la Banda Oriental: Montevideo, Uruguay, 2001.

95. Paolino, C.; Pittaluga, L.; Mondelli, M. Cambios en la Dinámica Agropecuaria y Agroindustrial del Uruguay y Las Políticas Públicas; Serie Estudios y Perspectivas CEPAL; CEPAL: Santiago de Chile, Chile, 2014.

96. Bértola, L.; Isabella, F.; Saavedra, C. El Ciclo Económico de Uruguay, 1998-2012; Documento de Trabajo Facultad de Ciencias Sociales; Facultad de Ciencias Sociales: Montevideo, Uruguay, 2014. 
97. Reyes Abadie, W. La Banda Oriental: Pradera, Frontera, Puerto; Ediciones de la Banda Oriental: Montevideo, Uruguay, 1966.

98. Barrán, J.; Nahum, B. Historia Rural del Uruguay Moderno; Ediciones de la Banda Oriental: Montevideo, Uruguay, 1978.

99. Instituto de Economía. El Proceso Económico del Uruguay; Fondo de Cultura Universitaria: Montevideo, Uruguay, 1969.

100. World Bank. The Changing Wealth of Nations: Measuring Sustainable Development in the New Millennium; The World Bank: Washington, DC, USA, 2011.

101. World Bank. Where Is the Wealth of Nations? Measuring Capital for the 21st Century; The World Bank: Washington, DC, USA, 2006.

102. Ding, N.; Field, B. Natural Resource Abundance and Economic Growth; University of Massachusetts Amherst: Amherst, MA, USA, 2005.

103. Sandonato, S. Capital Natural en Uruguay. 1990-2010. Propuesta Metodológica, Estimaciones y Ejercicios de Descomposición. Bachelor's Thesis, Universidad de la República, Montevideo, Uruguay, 2012.

104. Willebald, H.; Sandonato, S. Indicadores de Capital Natural; Nota Técnica No 1, Series Documentos del Reporte Anual 2014; Recursos Naturales y Desarrollo Red Sudamericana de Economía Aplicada: Montevideo, Uruguay.

105. Pearce, D.; Ulph, D. A social discount rate for the United Kingdom. In Environmental Economics: Essays in Ecological Economics and Sustainable Development; Pearce, D., Ed.; Edward Elgar Publishing: Cheltenham, UK, 1999; pp. 268-285.

106. Lindmark, M.; Andersson, L. Where Was the Wealth of the Nation? Measuring Swedish Capital for the 19th and 20th Centuries; Centre for Environmental and Resource Economics: Umea, Suecia, 2016.

107. De Rosa, M.; Sinisclachi, S.; Vilá, J.; Vigorito, A.; Willebald, H. La Evolución de Las Remuneraciones Laborales y la Distribución del Ingreso en Uruguay; Futuro en Foco, Cuadernos Sobre Desarrollo Humano: Montevideo, Uruguay, 2017.

108. Román, C.; Bertoni, R. Auge y ocaso Del carbón mineral en Uruguay. Un análisis histórico desde fines del siglo XIX hasta la actualidad. Rev. Hist. Econ. 2013, 31, 459-497.

109. Lampietti, J.; Dixon, J. To See the Forest for the Trees: A Guide to Non-Timber Forest Benefits; Environment Department Paper; World Bank: Washington, DC, USA, 1995.

110. Giles, J.; Mirza, S. Some Pretesting Issues on Testing for Granger Non Causality; Econometrics Working Paper; University of Victoria: Victoria, BC, Canada, 1999.

111. Lingarde, S.; Tylecote, A. Resource-rich countries' success and failure in technological ascent, 1870-1970: The Nordic countries versus Argentina, Uruguay and Brazil. J. Eur. Econ. Hist. 1999, 28, 77-114.

112. Bertino, M.; Bertoni, R.; Tajam, H.; Yaffé, J. Historia Económica Del Uruguay. Tomo III: La Economía Del Batllismo y de los Años Veinte; Fin de Siglo: Montevideo, Uruguay, 2005.

113. Moraes, I. La Pradera Perdida. Historia y Economía Del Agro Uruguayo: Una Visión de Largo Plazo, 1760-1970; Linardi y Risso: Montevideo, Uruguay, 2008.

114. Martín-Retortillo, M.; Pinilla, V.; Velazco, J.; Willebald, H. The goose that laid the golden eggs? Agricultural development in Latin America in the 20th century. In Agricultural Development in the World Periphery: A Global Economic History Approach; Pinilla, V., Willebald, H., Eds.; Palgrave Studies in Economic History; Palgrave Macmillan: Basingstoke, UK, 2018.

115. OPYPA-MGAP. El Desarrollo Agropecuario y Agro-Industrial de Uruguay; Reflexiones en el 50 Aniversario de la Oficina de Programación y Política Agropecuaria; MGAP-OPYPA: Montevideo, Uruguay, 2015.

116. Castro, P. Distribución Regional de la Producción y Geografía Económica. El Caso Del Agro en Uruguay (1870-2008). Master's Thesis, Universidad de la República, Montevideo, Uruguay, 2017.

117. Bertoni, R. Energía y Desarrollo. La Restricción Energética en Uruguay Como Problema: 1882-2000; CSIC: Montevideo, Uruguay, 2011.

118. Maddison, A. Ultimate and proximate growth causality: A critique of Mancur Olson on the rise and decline of nations. Scand. Hist. Rev. 1988, 36, 25-29. [CrossRef]

119. Abramovitz, M. Thinking about growth. In Thinking about Growth and Other Essays on Economic Growth and Welfare; Abramovitz, M., Ed.; Cambridge University Press: Cambridge, UK, 1989; pp. 3-79.

120. Rodrik, D. In Search of Prosperity. Analytic Narratives on Economic Growth; Princeton University Press: Princeton, NJ, USA, 2003. 
121. Szirmai, A. Proximate, Intermediate and Ultimate Causality: Theories and Experiences of Growth and Development; Working Paper Series on Institutions and Economic Growth; Maastricht Graduate School of Governance: Maastricht, The Netherlands, 2012.

122. Román, C.; Willebald, H. Formación de capital en el largo plazo en Uruguay, 1870-2011. Investig. Hist. Econ. 2015, 11, 20-30. [CrossRef]

123. Fleitas, S.; Rius, A.; Román, C.; Willebald, H. Contract Enforcement, Investment and Growth in Uruguay since 1870; Instituto de Economía: Montevideo, Uruguay, 2013.

124. Román, C. El PIB Histórico Por el Lado Del Gasto en Uruguay, 1870-2016: Una Primera Aproximación, Unpublished work.

125. Williamson, J. Land, labor and globalization in the third world, 1870-1940. J. Econ. Hist. 2002, 62, 55-85.

126. Bértola, L.; Lorenzo, F. Witches in the south: Kuzntes-like swings in Argentina, Brazil and Uruguay since the 1870. In The Experience of Economic Growth; van Zanden, J., Heikenen, S., Eds.; Amsterdam University Press: Amsterdam, The Netherlands, 2004.

127. Azar, P.; Bertino, M.; Bertoni, R.; Fleitas, S.; García Repetto, U.; Sanguinetti, C.; Sienra, M.; Torrelli, M. De Quiénes, Para Quiénes y Para Qué. Las Finanzas Públicas en el Uruguay del Siglo XX; Editorial Fin de Siglo: Montevideo, Uruguay, 2009.

128. Azar, P. Public Education Spending: Efficiency, Productivity and Politics. Ph.D. Thesis, Universtat Autònoma de Barcelona, Barcelona, España, 2017.

129. Roldós, J. A long-run perspective on trade policy, instability, and growth. In The Effects of Protectionism on a Small Country. The Case of Uruguay; Connolly, M., De Melo, J., Eds.; The World Bank: Washington, DC, USA, 1994.

130. Willebald, H. Land abundance, frontier expansion and appropriability: Settler economies during the first globalization. In Natural Resources and Economic Growth: Learning from History; Badía-Miró, M., Pinilla, V., Willebald, H., Eds.; Routledge Explorations in Economic History; Taylor \& Francis Group: London, UK; New York, NY, USA, 2015; pp. 248-270.

131. Schrijver, N. Sovereignty over Natural Resources: Balancing Rights and Duties; Cambridge University Press: New York, NY, USA, 2008.

132. Czelusta, J.; Wright, G. Resource-based growth past and present. In Natural Resources: Neither Curse nor Destiny; Lederman, D., Maloney, W., Eds.; World Bank/Stanford University Press: Stanford, CA, USA, 2007; pp. 183-211.

133. Angelsen, A. Cost-Benefit Analysis, Discounting, and the Environmental Critique: Overloading of the Discount Rate? Michelsen Institute Report; Chr. Michelsen Institute: Bergen, Norway, 1991.

134. Lindmark, M.; Acar, S. Sustainability in the making? A Historical estimate of Swedish sustainable and unsustainable development 1850-2000. Ecol. Econ. 2013, 86, 176-187. [CrossRef]

135. Chua, A.; Choong, W. A review of approaches to construct social discount rate. Sains Humanika 2016, 8, 37-42. [CrossRef]

136. Sen, A. On optimizing the rate of saving. Econ. J. 1961, 71, 479-496. [CrossRef]

137. Kay, J. Social discount rates. J. Public Econ. 1972, 1, 359-378. [CrossRef]

138. Brum, C.; Román, C.; Willebald, H. Un Enfoque Monetario de la Inflación en el Largo Plazo. El Caso de Uruguay (1870-2010); El Trimestre Económico: Montevideo, Uruguay, 2016.

139. Oddone, G. Restricciones para sostener el crecimiento: Lecciones y desafíos para las políticas públicas. In $L a$ Aventura Uruguaya. El País y el Mundo; Arocena, R., Caetano, G., Eds.; Debate: Montevideo, Uruguay, 2011; pp. 67-90.

(C) 2018 by the authors. Licensee MDPI, Basel, Switzerland. This article is an open access article distributed under the terms and conditions of the Creative Commons Attribution (CC BY) license (http://creativecommons.org/licenses/by/4.0/). 